\title{
JIHAD DALAM PERSPEKTIF AL-QUR'AN
}

\author{
Oleh: Amir Hamzah ${ }^{1}$ \\ ${ }^{1}$ Institut Agama Islam Muhammadiyah Sinjai, \\ Jl.Sultan Hasanuddin. No. 20 Balangnipa, Sinjai \\ E-Mail.puangamirhamzah@gmail.com,Tlp.:+6282188783286
}

\begin{abstract}
Abstrak
Makna jihad dalam al-Quran terjadi pemahaman yang bertingkat sesuai dengan karakter budaya dan kedalam ilmu yang dipahami dalam al-Quran. Pemaparan ayat dapat dipahami bawha makna Jihad dalam al-Quran pada umunya tidak ada yang mengarah pada Jihad fisik seperti difahami oleh sebagian Islam jalur keras, tetapi boleh dilakukan dalam kondisi tertentu jika meneggakan kehormatan dan katahuidan. Perlu paradigma baru pemahaman makna Jihad yang relevan dengan kondisi dewasa ini, khususnya bangsa Indonesia untuk mmberikan pilihan-pilihan model jihad yang lebih besar pengaruhnya terhadap perbaikan kualitas hidup masyarakat Indonesia seperti berjihad melawan berbagai macam ketidakadilan, jihad melawan korupsi, dan kebodohan. Jihad harus memiliki strategi yang jitu tidak boleh hanya mengandalkan semangat dalam melakukan aktifitas kemaslahatan umat. Inilah Jihad yang menurut penulis lebih besar pengaruhnya terhadap ekosistem kehidupan manusia, dibanding Jihad yang sifat fisikli merusak pola hidup masayarakat dan berbahaya terhadap ekosistem kemanusiaan.
\end{abstract}

\section{Kata Kunci: Jihad dan Al-Qur'an}

\section{PENDAHULUAN}

$\mathrm{K}$ uliah umum Quraish pada tanggal 6 Nopember 2010 di ruang pasca UIN Alauddin yang diikuti oleh semua mahasiswa S2 dan S3. Quraish dengan tegas mengatakan bahwa tidak boleh mengatakan terminologi ilmiah yang ada sekarang sebagai produk ilmiah yang mutlak kebenaranya karena produk ilmiah yang ada sekarang adalah kesepakatan para ilmuan dahulu yang belum tentu relevan dengan kondisi sekarang.1

Dari paradigma Quraish ini, ada indikasi perlu ada pola baru yang sesuai dengan seting sosial masyarakat dalam memahami nilai-nilai ilmiah dalam al-Quran. Begitu pula memahami ayat tentang Jihad dalam al-Quran perlu paradigma baru berdasarkan kebutuhan umat manusia sesuai kondisi sosial masyarakat. Semangat al-Quran yang dipahami tentang makna jihad hemat penulis prinsipnya memiliki kekuatan dahsyat untuk merubah pola hidup manusia dari tradional menjadi moderen.

Pemahaman jihad yang keliru dapat melahirkan sadisme, terorisme dan pembunuhan orang lain dengan cara membabi buta. Untuk menyikapai keragaman memahami al-Quran ini hemat penulis berdasarkan pada tingkatan kedalam keilmuan dan geonologi pendidikan serta referensi literatur yang dikonsumsi. Dalam perspektif teori komunikasi Mursyid dikutip Mulyana bahwa semakin eksklusif

1 M. Quraish Shihab, Kuliah Umum S2 dan S3 Pada tanggal 6 Nopember 2010 Jam 11.00 s/d 12.30 wit di Ruang Pascasarjana Universitas Negeri Alauddin Makassar. 
pola pikir seseorang nerarti semakin eksklusif bacaannya, begitupun sebaliknya.2 Dalam konteks kompleksitas pemahaman jihad umat Islam dewasa ini, juga bervariasi sesuai model-model Islam yang dipetakan oleh Abudin Nata.

Abudin Nata dalam konteks keindonesiaan membagi model pemahaman umat Islam menjadi 13 model di antaranya: Islam aktual, Islam rasional, Islam tradisional, Islam kultural, Islam transformatif, Islam kontekstual, Islam teologis normatif, Islam eksklusif, Islam inklusif plural, Islam fundamentalis, Islam modernis, Islam esoteris, dan Islam modernis.3 Perbedaan pemahaman ini memberikan peluang untuk berbeda memahami makna jihad ada yang ekstrim, demokratis dan semi demokratis. Menurut Ibnu Khaldun sosiolog yang dikutip wulan mengatakan bahwa ekpresi orang sangat tergantung pada bacaannya dan budayanya.4 Jika budaya senang berperang maka kecendrungan memahami ayat tersebut ke arah berperang, begitu seterusnya.

Presepsi penulis dari penjelajahan stigma para ilmuan yang dibentangkan lewat jaringan global (internet) difahami latar belakang para teroris melakukan kegiatan sadisme, teror akibat dari pemahaman ayat al-Quran Surah al-Taubah/9: 111 yang menjadi senjata bagi pelaku bom bunuh diri dalam melakukan aksi jihad melawan orang kafir.

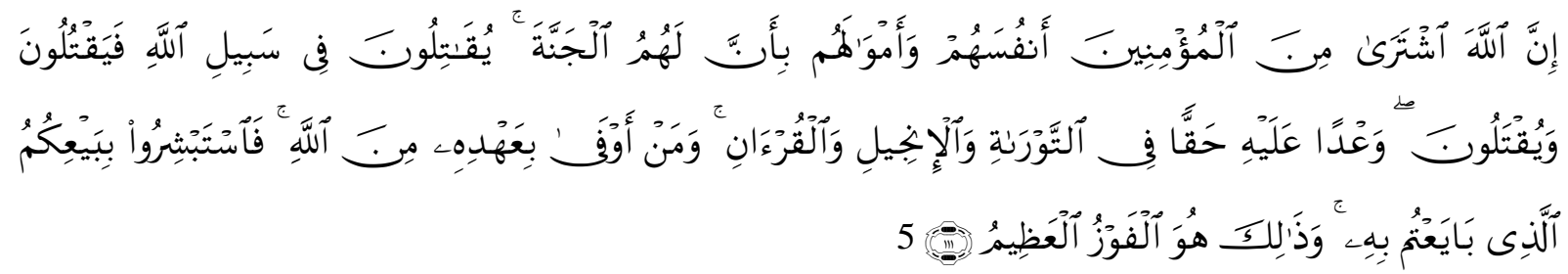

Terjemahnya:

"Sesungguhnya Allah membeli dari orang-orang mukmin, baik diri maupun harta mereka dengan memberikan surga untuk mereka. Mereka berperang pada jalan Allah; sehingga mereka membunuh atau terbunuh. (sebagai) janji yang benar dari Allah; dalam Taurat, Injil dan AlQuran. dan siapakah yang lebih menepati janjinya selain Allah? Maka, bergembiralah dengan jual beli yang telah kamu lakukan itu, dan demikian Itulah kemenangan yang agung".6

Ayat di atas QS. al-Taubah/9: 111 sering kali difahami sebagai landasan untuk melakukan jihad fisik.7 Pemahaman ini juga menjadi media melegetimasi aksi para teroris yang dalam mendoktrin anggotanya untuk melawan para penguasa yang durjana.8 Untuk lebih mendalam penulis fokuskan objek permasalahan makalah ini pada 3 rumusan masalah:

2 Deddy Mulayana, Nuansa-Nuansa Komunikasi: Meneropong politik dan Budaya Komunikasi Masyarakat Kontemporer, (Cet. III;Bandung: PT. Remaja Rosda Karya, 2005), h. 61.

3 H. Abuddin Nata, Peta Keragaman Pemikiran Islam Indonesia, (Cet. II;Jakarta: PT. Rajagrafindo Persada, 2001), h. VII. Lebin lengkapnya baca Abudin Nata.

4 Dewi Wulan Sari, Sosiologi: Konsep dan Teori, (Cet. I; Bandung: PT. Refika Aditama, 2009),h.73.

5Software Alquran Digital, Alquran Inword, versi 13 tahun 2006. QS Attaubah/9: 111.

6 Departemen Agama Republik Indonesia, Alquran dan Terjemah Perkata Type Hijaz.Syamila Alquran, (Cet. Jakarta: Sigma, 2007), h.204.

7 M. Quraish Shihab, Wawasan Alquran: Tafsir tematik atas pelbagai Persoalan umat (Cet. I;Jakarta: Mizan, 2007), h. 659.

8 Iman Samudra, Islam Pembebasan Islam dari Gerakan Kafir Zionisme artikel yang diakses pada www.http.imam_samudra.id.com. pada web Iman Samudra diakses pada tanggal 23 Oktober 2010 12: 34 wit. 
1. Bagimana pengertian jihad?

2. Bagimana pandangan jihad dalam al-Quran?

\section{PEMBAHASAN}

Perlu penulis berikan termonilogi dalam judul makalah ini untuk menghindari pemahaman yang keliru dalam penggunaan istilah dalam makalah ini. Paradigma baru dalam memahami makna Jihad dalam al-Quran dalam konteks kekinian yang penulis maksudkan adalah: Adanya pola pemahaman jihad sesuai konteks budaya, dan tradisi yang relevan dengan naluri masyarakat yang sesuai semangat al-Quran dan konteks kekinian.

\section{A. Pengertian Jihad}

Pengertian Jihad menurut bahasa berasal dari kata jahada, artinya tenaga, usaha atau kekuatan. Menurut istilah jihäd artinya bersungguh-sungguh mencurahkan segenap fikiran, kekuatan, dan kemampuan untuk mencapai tujuan.9

merupakan suatu kata yang sangat populer didengar oleh telinga kita dan lidah kitapun sudah sangat fasih untuk mengucapkan kata tersebut, padahal sering kita tidak mampu untuk menjelaskan mengenai jihăd itu sendiri dalam arti yang sebenarnya.10 Dalam benak sebagian orang, ketika disebut kata jihăd, maka secara otomatis, mengidentikkan dengan perang melawan musuh. Tetapi benarkah pemahaman kita tentang jihād seperti ini. Pengertian atau pemaknaan jihàd yang tidak tepat pada akhirnya akan berakibat menurunkan makna (moral) sebenarnya dari jihād itu sendiri.11

Jihad adalah usaha dengan segala daya untuk mencapai kebaikan; upaya membela agama dengan mengorbankan harta dan nyawa; perang suci melawan orang kafir untuk mempertahankan agama Islam; berjihad berjuang atau berperang di jalan Allah.12

Jihad merupakan suatu ajaran yang pokok dari Islam dalam rangka untuk mempraktekkan prinsip amar maruf dan nahỉ munkar guna menjadikan fungsi khalifah dari manusia menjadi realita. Jihad mendapat perhatian penting dalam Islam, sehingga Allah-pun menjanjikan balasan yang besar kepada orang-orang yang berjihad di jalan-Nya.

Jadi, pengartian Jihad sangatlah kondisional dimana pemahaman substansi dari jihad (atau lebih lagi dalam usaha pengartian jihad yang paling baik) tidaklah terlepas dari usaha-usaha ijtihād manusia dalam membaca kondisi dan mendialogkan antara wahyu Alquran dan kehidupan nyata ini. Perlu ada jihad motivasi diri untuk mendapat inspirasi dari pesan-pesan Al-Quran untuk memahami fenomena-fenomena alam seperti gempa, banjir dan gempa kemanusiaan yang meresahkan pola kehidupan sosial kemasyarakatan.

9 Ahsin A. W. Al-Hafiz, Kamus Ilmu Al-Quran, (Cet. I; Jakarta: Hamzah, 2005), h. 138

10 Departemen Agama RI, Yayasan Penyelenggara Penerjemah/Penafsir Al-Quran, Syamil Al-Quran Terjemah Per-Kata, Syamil International, 2007.

11 Munawwir, A.W. Kamus Al Munawwir Arab-Indonesia, (Cet. XXV; Surabaya: Pustaka Progresif, 2002), h. 22.

12 Balai Bahasa Departemen pendidikan dan Kebudayaan Republik Indonesia, Kamus Besar Bahasa Indoensia (Cet. Pusat Bahasa, 2008), h .637 
Inpirasi dari Alquran tentunya membutuhkan Jihad untuk mengetahui apa penyebab secara hakikat hejolak kemanusian dan gejolak alam yang kerpa kali tidak terkendali oleh ekosistem kehidupan. Dengan demikian perlu ada takhrij (istilah hadis) ayat yang berhubungan dengan makna jihād.

Menurut kajian Quraish kata jihad terulang sebanyak 41 kali dengan berbgai bentuknya. Sedngkan Ibnu al-Fāris Maqāyīs al-Lughah jihad terdiri dari huruf (ه), (ه), (د) pada awalnya mengandung arti kesulitan dan kesukaran yang mirip dengannya. Kata Jihad terambil dari kata jahd yang berarti letih/sukar Jihad memang sulit dan menyebabkan keletihan.

Secara bahasa (etimologi) ia berasal dari kata "juhd" atau "jahd". makna etimologi adalah kesungguhan, kemampuan maksimal, kepayahan dan usaha yang sangat melelahkan.13 Dari kata ini juga terbentuk kosa-kata "ijtihād". Tetapi yang terakhir ini lebih mengarah pada upaya dan aktifitas intelektual yang serius dan melelahkan. Dalam terminologi sufisme juga dikenal istilah "mujahadah", sebuah usaha spiritual yang intens, bahkan mungkin sampai pada tingkat ekstase. Orang yang berjuang di jalan Allah dengan sungguh-sungguh disebut mujahid atau mujahidin untuk orang banyak.14

\section{B. Pandangan para Ulama Tafsir}

\section{Ayat Jihad Menurut Quraish Shihab}

Pemahaman jihad menurut Quraish adalah cara mencapai tujuan dengan tidak mengenal put us asa, menyerah, berkeluh kesah. Tetapi jihad tidak dapat dilakukan tanpa modal dan perencaan yang strategis. Tema-tema yang mengandung makna jihat dala al-Quran Berikut ini penulis paparkan ayat-ayat jihad menurut Quraish Shihab.

QS. Al-Ambiya/21: 17, 18.

QS. At-Tahrim/21: 9

QS. Alimran/3:142

QS. Al-Qashas/28: 50 .

QS. Al-Baqarah/2: 214, 155,

QS. Yusuf/12: 53.

218, 168, 268,216, 190, 193, 191, 192

QS. Al-'Araf/7: 200, 201

QS. At-Taubah/9:19, 24, 44, 79, 19,24,44, 81

QS. Al-Anfal/8: 65, 60, 66, 58

QS. Al-Ankabut/29: 6, 69.

QS. An-Nisa4:76, 120

QS. Luqman /31: 15

QS. Al-Anfal/8: 61, 62

QS. Al-Hajj/22: 78.

QS. Al-Baqarah/2: 216.15

13 A.W. Munawwir, Kamus Al Munawwir Arab-Indonesia, (Surabaya: Pustaka Progresif), hal 217.

14 Sami bin Abdullah bin Ahmad al-Maghluts, Atlas Sejarah Para Nabi dan Rasul, Mendalami Nilainilai Kehidupan yang Dijalani Para Utusan Allah, (Jakarta: Obeikan Riyadh, Almahira, 2008.

15 op. cit., Quraish Shihab. 


\section{Klasifikasi Makna Jihad dalam Al-Quran}

Al-Quran menyebut kata jihad dalam sejumlah ayat kurang lebih 41 ayat yang tersebar dalam mushaf al-Quran yang baru ditemukan.16 Hal ini menurut hemat penulis tidak menut up kemungkinan masih ada ayat jihad lain yang belum terungkap.

\begin{tabular}{|c|c|c|c|}
\hline Jumlah Ayat & Madaniyah & Makiyah & Pola Ayat \\
\hline 2 Ayat & 2 Ayat & - & جَا هَدَ \\
\hline 2 Ayat & 2 Ayat & - & جَا هِدِ \\
\hline 2 Ayat & 1 Ayat & 1 Ayat & جَا هَدَالََْ \\
\hline 1 Ayat & - & 1 Ayat & جَا هِدهُهُم \\
\hline 11 Ayat & 9 Ayat & 2 Ayat & جَا هَدُوا \\
\hline 4 Ayat & 4 Ayat & - & جَا هِدُوا \\
\hline 1 Ayat & 1 Ayat & - & جِهَادٍ \\
\hline 2 Ayat & 1 Ayat & 1 Ayat & جِهَادًا \\
\hline 1 Ayat & 1 Ayat & - & جِهَا دِدِ \\
\hline 5 Ayat & 2 Ayat & 3 Ayat & جَهَُ \\
\hline 1 Ayat & 1 Ayat & - & جُهَدَهُم \\
\hline 1 Ayat & 1 Ayat & - & الألُجَا هِدُون \\
\hline 3 Ayat & 3 Ayat & - & المُجَا هِدِينَ \\
\hline 1 Ayat & 1 Ayat & - & يُجَا هِدُ \\
\hline 2 Ayat & 2 Ayat & - & يُجَا هِدُوا \\
\hline 1 Ayat & 1 Ayat & - & يُجَا هِدُونَ \\
\hline 1 Ayat & 1 Ayat & - & تُجَا هِدْون \\
\hline 41 Ayat & 33 Ayat & 8 Ayat & Total \\
\hline
\end{tabular}

\section{Jihad dan Qital}

Melihat hal ini, pemaknaan jihäd dengan perang tampaknya tidak lepas dari latar belakang sejarah perkembangan Islam sendiri. Ia muncul ketika Islam bergerak ke arena pergulatan politik dalam komunitas muslim dan non-muslim. Akan tetapi jihād perang pada masa Nabi di Madinah lebih dilakukan dalam kerangka membela diri dari agresi dan kekerasan. Dalam banyak ayat, perang bukanlah inisiatif Islam. Al-Quran melarang kaum muslimin memerangi orang-orang yang tidak melakukan penyerangan atau pengusiran.17

Al-Quran selain menggunakan kata jihad, juga mempergunakan kata "qital" untuk menunjukkan dan sekaligus membedakan arti yang lebih spesifik dari jihad perang dengan Jihad yang lain. Qital berasal dari kata "qatala" yang berarti "memerangi atau membunuh", makna qatala ini

16 Al-Quran Digital, Software dan lihat juga, Shihab, M. Quraish. Wawasan Al-Quran Tafsir Maudhu'i atas Pelbagai Persoalan Umat, Bandung: Penerbit Mizan, 2007.

17 A.W. Munawwir, Kamus Al Munawwir Arab-Indonesia, (Surabaya: Pustaka Progresif), h. 217. 
mengacu pada perjuangan dengan mengangkat senjata untuk memerangi musuh yang mengancam eksistensi ummat Islam. Qital(Pembunuhan) merupakan bagian dari jihād, sehingga sering digunakan kata "jihad qital" untuk menunjukkan perjuangan mengangkat senjata itu sendiri. Jihad qital banyak sekali dilakukan oleh Nabi Muhammad dan juga para sahabat beliau dalam rangka mempertahankan eksistensi agama dan ummat Islam.18

Al-Quran, dalam ayat-ayat Makiyah, perkataan Jihad atau al-jihad lebih menunjukkan kepada makna-makna am (umum) dari amar maruuf dan nahi munkar. Ayat Makiyah ini dapat dijumpai di surat al-Ankabut/29: 6.

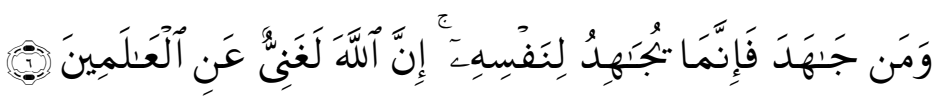

Terjemahnya:

"Barang siapa yang berjihad, maka sesungguhnya jihadnya untuk dirinya sendiri (berakibat kemaslahat an baginya)".19

Dan al-Ankabut:

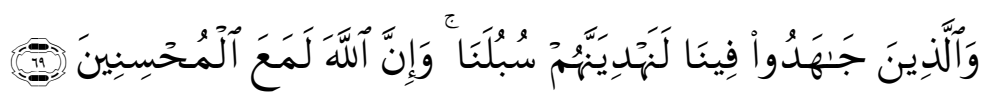

Terjemahnya:

"Dan orang-orang yang berjihad untuk (mencari keridhaan) Kami, benar- benar akan Kami tunjukkan kepada mereka jalan-jalan kami. dan Sesungguhnya Allah benar-benar beserta orang-orang yang berbuat baik".20

Sedang dalam ayat-ayat Madaniyah, akan kita jumpai makna kata Jihad yang lebih spesifik ke arah Jihad qital yaitu memerangi musuh. Ayat-ayat ini bisa dijumpai pada At-Taubah ayat 41 :

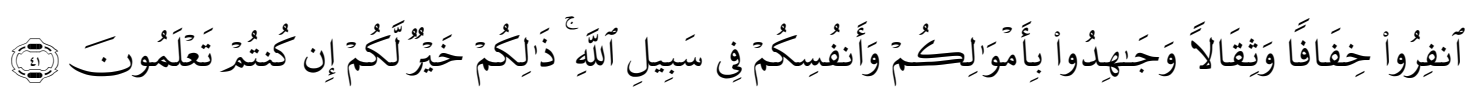

Terjemahnya:

"Berangkatlah kamu baik dalam keadaan merasa ringan ataupun merasa berat, dan berjihadlah dengan harta dan dirimu dijalan Allah. Yang demikian itu adalah lebih baik bagimu jika kamu mengetahui".

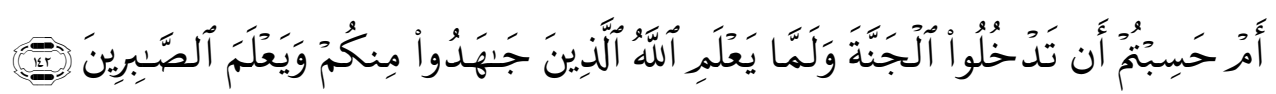

Terjemahnya:

"Apakah kamu mengira bahwa kamu akan masuk surga, padahal belum nyata bagi Allah orangorang yang berjihad di antaramu dan belum nyata orang-orang yang sabar". 21

Jihad dapat berarti: 1 . berperang untuk menegakkan Islam dan melindungi orang-orang Islam;

2. memerangi hawa nafsu; 3. mendermakan harta benda untuk kebaikan Islam dan umat Islam; 4.

Memberantas yang batil dan menegakkan yang hak. Meski ayat-ayat Madaniyah lebih spesifik kepada makna jihad qital, tetapi kerangka jihad yang dipakai itu sendiri tidak lepas dari prinsip dasar makna jihad yang lebih luas yaitu amar maruf dan nahi munkar.

18 Fuad Abdul Baqie Muhammad, Nu'jamul Mufahras li Afadhil Qur'an, Beirut: Dar El Marefah. 2005.

19 Departemen Agama Republik Indonesia, Al-Qur'an Al-Karim Tajwid dan Terjemahannya (PT. Syamila Cita Media, 2007).

20 Departemen Agama Republik Indonesia, .....ibid

21 Departemen Agama Republik Indonesia, ... ibid 


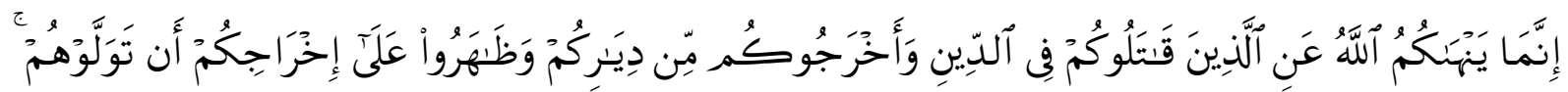

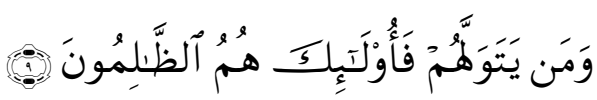

Terjemahnya:

"Sesungguhnya Allah hanya melarang kamu menjadikan sebagai kawanmu orang-orang yang memerangimu karena agama dan mengusir kamu dari negerimu, dan membantu (orang lain) untuk mengusirmu. dan Barangsiapa menjadikan mereka sebagai kawan, Maka mereka itulah orang-orang yang zalim".22

Sebaliknya terhadap orang-orang yang tidak memerangi kamu, Alquran menganjurkan untuk berlaku baik dan adil. "Allah tiada melarang kamu untuk berbuat baik dan berlaku adil terhadap orang-orang yang tiada memerangimu karena agama dan tidak pula mengusir kamu dari negerimu.

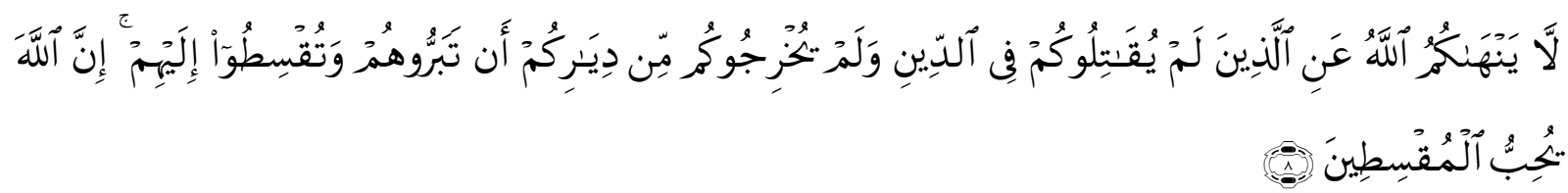

Terjemahnya:

"Allah tidak melarang kamu untuk berbuat baik dan Berlaku adil terhadap orang-orang yang tiada memerangimu karena agama dan tidak (pula) mengusir kamu dari negerimu. Sesungguhnya Allah menyukai orang-orang yang Berlaku adil”.

\section{Jihad terhadap Orang Munafik dan Orang Kafir}

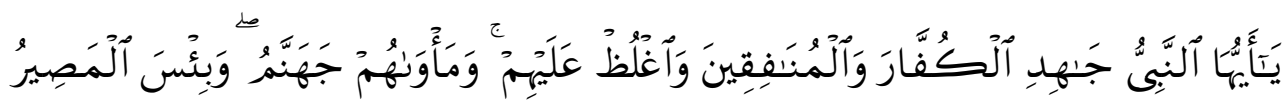

Terjemahnya:

"Wahai Nabi berjuanglah (jahid, yang berasal dari kata jihad) melawan kaum kafir dan kaum munafik dan bersikap keraslah terhadap mereka. Dan tempat tinggal mereka adalah jahannam. Dan itulah tempat kembali yang seburuk-buruknya. (QS. At-Taubah/9:73

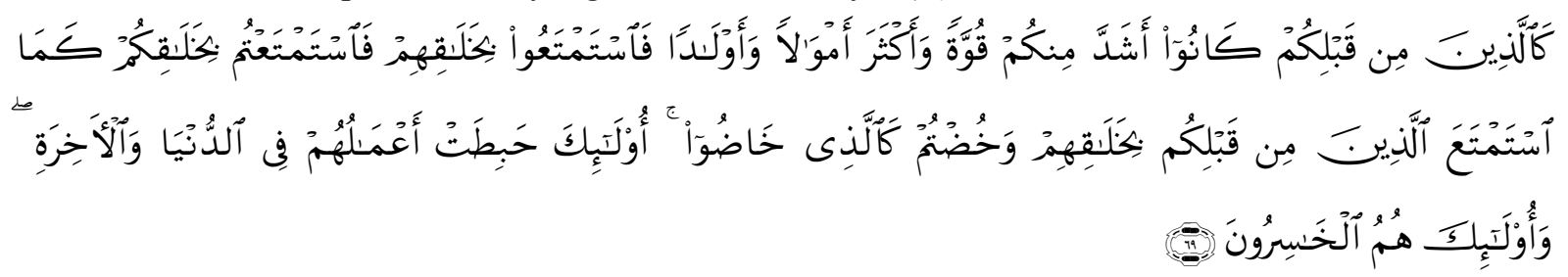

Terjemahnya:

"(Keadaan kamu Hai orang-orang munafik dan musyrikin) adalah seperti Keadaan orang-orang sebelum kamu, mereka lebih kuat daripada kamu, dan lebih banyak harta dan anak-anaknya dari kamu. Maka mereka telah menikmati bagian mereka, dan kamu telah menikmati bagian kamu sebagaimana orang-orang yang sebelummu menikmati bagiannya, dan kamu mempercakapkan (hal yang batil) sebagaimana mereka mempercakapkannya. mereka itu amalannya menjadi sia-sia di dunia dan di akhirat; dan mereka Itulah orang-orang yang merugi". (QS. al-Taubah/9:69.23

Ayat ini memerintahkan Rasulullah Saw. untuk berjuang melawan kaum kafir dan kaum munafik sekaligus. (Kaum munafik adalah kaum yang pada lahiriyahnya Muslim dan hidup ditengah-

22 Departemen Agama Republik Indonesia, Al-Qur'an Al-Karim Tajwid dan Terjemahannya PT. Syamila Cita Media, 2007.

23 Departemen Agama Republik Indonesia, Al-Qur'an Al-Karim Tajwid dan Terjemahannya PT. Syamila Cita Media, 2007. 
tengah kaum Muslimin dan diperlakukan sebagai orang Islam dalam segala hal. Mereka juga pergi ke Masjid dan menjalankan shalat bersama-sama kaum Muslimin lainnya. Mereka juga membayar zakat, malahan kadang-kadang mereka juga ikut bertempur bersama-sama kaum Muslimin lainnya melawan kaum kafir). Memerangi mereka secara perang fisik adalah tak mungkin sama sekali dan perang fisik terhadap mereka memang tak pernah dilakukan.24

Tetapi ini tidak berarti bahwa hanya kedua objek itu yang harus dihadapi dengan jihad, karena dalam ayat-ayat lain disebutkan musuh-musuh yang dapat menjerumuskan manusia kedalam kejahatan, yaitu setan dan nafsu manusia sendiri. Keduanya pun harus dihadapi dengan perjuangan.

Penafsiran para ulama tentang makna jihad dalam al-Quran terdapat 41 ayat angka ini penulis dapat pada buku Quraish Shihab pada wawasan tafsir tematik. Menurut Quraish ada kesalapahaman tentang pemaknaan ayat-ayat jihad, hal ini akibat dari perkataan jihad ini muncul ketika peran fisik dikumandangkan.25 Hemat penulis jihad model ini, difahami secara turun-temurun, tanpa ada pencerahan kembali apa hakikat dari makna jihad sesungguhnya.

\section{Jihad Melawan Musuh}

Pemahaman ayat dalam al-Quran yang berhubungan dengan jihad setuju dengan pandangan Quraish bahwa ada kekeliruan memahami sejarah tentang jihad. Jihad difahami dalam konteks peran fisik sehingga cendrung pemaknaannya hanya sebatas peran fisik. Dalam konteks ini Rasulullah memberikan informasi ilmiah terhadap permasalahan ini sebagaimana hadis yang diriwayatkan oleh Rasulullah.

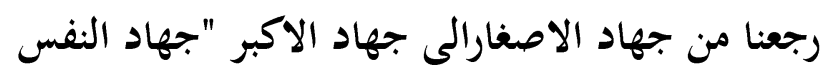

Artinya:

"Kita kembali dari jihad terkecil menuju jihad terbesar, yakni jihad melawan hawa nafsu".

Jihad disini mempunyai pengertian yang sama artinya dengan jihad yang dipakai pada ayatayat Makiyah yaitu jihad dengan mempergunakan Qur'an Suci, sebagaimana juga dijelaskan oleh surat al-Furqan ayat 52. Dalam wahyu Madaniyah yang lainpun kata-kata 'gihad"digunakan dalam arti yang sangat luas dan tidak terbatas dalam pengertian "perang fisik" saja tetapi meliputi arti yang umum yakni “berjuang” yang mencakup perang rohani maupun pertempuran fisik. Qur'an berfirman sbb:

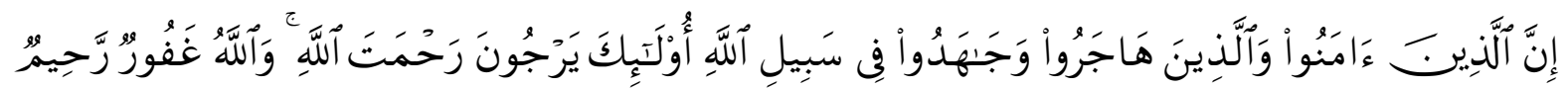

Terjemahnya:

"Sesungguhnya orang-orang yang beriman dan orang-orang yang hijrah dan berjuang (jahadu) dijalan Allah, mereka mengharapkan rahmat Allah."QS. Alimran/2:218

24 Syauqi Abu Khalil, Atlas Al-Quran, Membuktikan Kebenaran Fakta Sejarah yang Disampaikan alQur'an secara Akurat disertai Peta dan Foto, Dar al-Fikr Damaskus, Almahira Jakarta, 2008.

25 M. Quraish Shihab, Tafsir Tematik atas Pelbagai Persoalan Umat (Cet. I;Jakarta: Mizan Media Utama, 2007), h. 667 
Jihad dalam kedua ayat ini bisa diterapkan kepada orang-orang yang bertempur secara fisik, tetapi dapat pula diterapkan kepada orang-orang yang berjuang membasmi kekafiran dan kejahatan secara perjuangan rohani.

Dalam wahyu Madaniyah yang lain lagi diuraikan pula tentang kata "shabirin" (orang-orang yang sabar) berdampingan dengan kata "mujahidun" (orang-orang yang berjuang) dalam satu ayat sebagaimana kata-kata itu diuraikan dalam wahyu Makiyah.

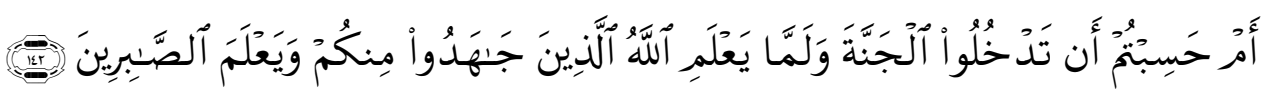

Terjemahnya:

"Apakah kamu mengira bahwa kamu akan masuk sorga, padahal Allah belum melihat bukti, siapa diantara kamu yang berjuang (jahadu) dan belum melihat pula orang yang sabar".(QS. Āli Imran/3:142.

Dalam berapa Hadistpun diterangkan makna dari kata "jihad", tetapi tidak satupun Hadist tersebut yang mengartikan perkataan tersebut dengan arti yang yang sempit dan khusus "perang fisik". Misalnya dalam Hadits berikut ini dikatakan:

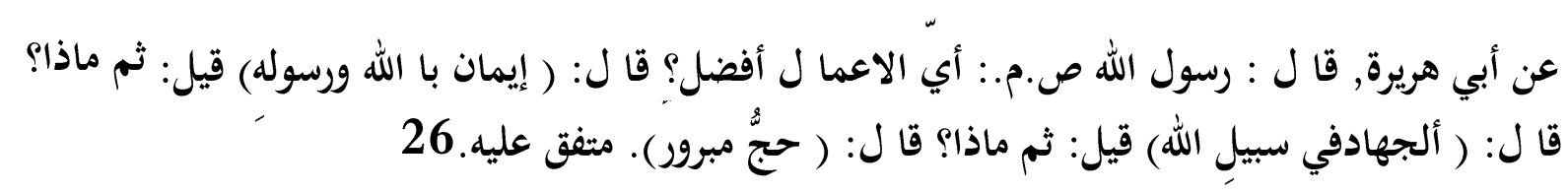

Artinya:

"Rasulullah SAW bersabda: "Ibadah Haji adalah Jihad yang paling mulia". (Bukhari)27

Jihad merupakan aktivitas yang unik, menyeluruh, dan tidak dapat dipersamakan dengan aktivitas lain-sekalipun aktivitas keagamaan. Tidak ada satu amalan keagamaan yang tidak disertai dengan jihad.28 Paling tidak, jihad diperlukan untuk menghambat rayuan nafsu yang selalu mengajak pada kedurhakaan dan pengabaian tuntunan agama. Karena itu, seorang Mukmin pastilah mujahid, dan tidak perlu menunggu izin atau restu untuk melakukannya. Ini berbeda dengan orang munafik. Al-Quran menegaskan,

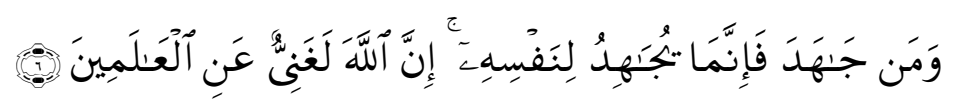

Terjemahnya:

"Barang siapa yang berjihad, maka sesungguhnya jihadnya untuk dirinya sendiri (berakibat kemaslahatan baginya)". (QS A1-Ankabut/29: 6).29

\section{Jihad Menghadapi Setan dan Nafsu}

Seperti dikemukakan di muka, sumber segala kejahatan adalah setan yang sering menggunakan kelemahan nafsu manusia. Setan adalah nama yang paling populer di antara namanama si perayu kejahatan. Begitu populernya sehingga menyebut namanya saja, terbayanglah, kejahatan itu. Nama setan dikenal dalam ketiga agama samawi: Yahudi, Nasrani, dan Islam. Konon

26 Al-Hafizh Zaki Al-Din 'Abd Al-'Azhum Al Mundziri, Ringkasan Shahih Muslim, Al-Maktab AlIslami, Beirut, dan PT. Mizan Pustaka, Bandung, 2008.

27 Al-Bayan, Shahih Bukhari Muslim, Jabal, Bandung, 2008.

28 Muhammad Fu'ad Abdul Baqi, Mutiara Hadist Shahih Bukhari Muslim, PT. Bina Ilmu, 1979

29 Departemen Agama Republik Indonesia, Al-Qur'an Al-Karim Tajwid dan Terjemahannya (Bandung: PT. Syamila Cita Media, 2007). 
kata setan berasal dari bahasa ibrani, yang berarti "lawan/musuh." Tetapi, barangkali juga berasal dari bahasa Arab, syaththa yang berarti "tepi", dan syatha yang berarti "hancur dan terbakar", atau syathatha yang berarti "melampaui batas".

Setan, karena jauh dari rahmat Allah, akan hancur dan terbakar di neraka. Setan selalu di tepi, memilih yang ekstrem dan melampaui batas. Bukankah seperti sabda Nabi saw., "Khair alumur al-wasath" (Sebaik-baik sesuatu itu adalah yang moderat, yang di tengah). Demikian halnya kedermawanan yang berada di antara keborosan dan kekikiran, dan keberanian berada di tengah antara takut dan ceroboh. Konon kata devil di dalam bahasa Inggris terambil dari kata do yang berate melakukan dan evil yang berarti kejahatan. Dengan demikian setan adalah "yang melakukan kejahatan."

Setan terjahat bernama iblis. Sebagian pakar Barat berpendapat bahwa kata iblis asalnya adalah dari bahasa Yunani diabolos yang mengandung arti memasuki dua pihak untuk menghasut dan memecah belah. Diabolos adalah gabungan Dia yang berarti ketika, dan Ballein yang berarti melontar. Hingga kemudian secara majazi berarti demikian. Dari bahasa Arab, iblis diduga terambil dari akar kata ablasa yang berarti putus harapan, karena iblis telah putus harapannya masuk ke surga. Demikian tulis Abbas al-Aqqad dalam bukunya, iblis.

\section{Paradigma Memahami Makna Jihad}

\section{Makna Jihad dalam Konteks Kekinian}

Penulis menjelajahi pengertian kata jihad dalam al-Quran dalam berbagai macam ahli tafsir mengungkapkan bahwa jihad adalah usaha yang sugguh-sungguh untuk mencapai sesuatu yang dilakukan dengan cara profesional yang didukung oleh modal yang mapan. Paradigma inilah yang digunakan untuk mendefinisikan makna jihad dalam konteks kekinian.

Inspirasi dari hadis Rasulullah tentang jihad besar yakni jihad melawan hawa napsu sendiri, ini menjadi pondasi sisi kemuliyaan seseorang jika sadar dan mampu melawan pengaruh negatif dalam diri untuk menuju pada kecerdasan individual setiap individu maka seara otomatis dapat mempengaruhi pola perkembangan kehidupan dunia moderen.30 Prilaku jihad individual setiap hari harus kontinyu dilakukan oleh setiap umat manusia dengan usaha jihad melawan hawa napsu dan berusaha keras untuk memperbaiki budipekerti, berjihad untuk berbicara yang baik, jihad membantu orang yang susah, juga untuk hidup yang mapan, berkorban untuk kehidupan yang menakjubkan untuk diri sendiri dan lingkungan sekitar hemat penulis inilah jihad akbar yang relevan dalam konteks kekinian.

Sekiranya semua orang dapat menyadari dan mulai dari sekarang melakukan jihad untuk melawan hawa napsunya maka secara otomatis perubahan sosial dalam setiap lingkungan masyarakat kearah yang lebih baik bisa tercapai suasana yang kondusif dan menyenangkan. Misalnya jihad dalam

30 H.M. Arifin, Psikologi Dakwah: Suatu Pengantar, (Cet. VI;Jakarta:Bumi Putra, 2004), h.5 
melakukan ibadah haji khususnya di Indonesia berjuta-juta penduduk muslim telah mengorbankan cinta tetapi perubahan secara signifikan belum dirasakan. Jihad individual (jihad melawan diri sendiri) yakni mengorban rasa cinta baik fisik dan non fisik untuk penyerahan diri hanya semata kepada Allah tetapi ini tingkat jihad paling tinggi mungkin kita tidak ada dalam level ini. wallahu wa'lam.

Hamka dalam sebuah ceramah tasawuf yang penulis transkrip lewat ceramahnya mengatakan bahwa jihad penyucian diri adalah bentuk jihad akbar yang dari sifat serakah, ingin menang sendiri senang lihat orang susah, bangga kalau kaya sendiri, dan suka mencari keresahan terhadap dirinya dan orang lain. Jihad fisik ada akhirnya tetapi Jihad melawan hawa napsu tiada akhirnya.31

\section{Jihad Rohani}

Sementara itu, jihad dalam pengertian perjuangan moral dan spiritual, jihad tanpa kekerasan dan bersenjata telah dengan sangat jelas dikemukakan dalam banyak ayat Alquran. Perjuangan moral dan spiritual adalah perjuangan menegakkan keadilan, kebenaran dan kesalehan. Semua tema ini terangkum dalam istilah yang sangat populer dan menjadi inti keseluruhan perjuangan dalam kehidupan orang-orang beriman; "amar ma'ruf nahi munkar".

Perintah al-Qur'an mengenai ini tidak dibatasi hanya terhadap laki-laki, tetapi juga perempuan. Meskipun pandangan-pandangan konservatif telah membatasi perjuangan kaum perempuan hanya dalam ruang sempit bernama keluarga, tetapi pandangan Tauhid, paradigma kesetaraan manusia dan keadilan, memberikan peluang kepada kaum perempuan untuk berjihad dalam ruang-ruang sosial, ekonomi, politik dan kebudayaan. 32

Jihad membangun kebersamaan dan tanpa diskriminasi, menegakkan keadilan dan menghapuskan segala bentuk kezaliman, serta mewujudkan kesalehan budaya dan membatasi keserakahan nafsu, harus menjadi cara-cara kehidupan manusia ke depan. Inilah makna jihad akbar sekaligus sebuah bentuk kerahmatan semesta yang menjadi cita-cita Islam.

Jihad juga mengandung arti "kemampuan"yang menuntut sang mujahid mengeluarkan segala daya dan kemampuannya demi mencapai tujuan. Karena itu Jihad adalah pengorbanan, dan dengan demikian sang mujahid tidak menuntut atau mengambil tetapi memberi semua yang dimilikinya. Ketika memberi, dia tidak berhenti sebelum tujuannya tercapai atau yang dimilikinya habis.

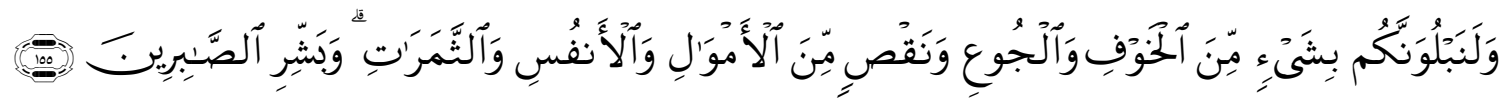

Terjemahnya:

"Dan sungguh pasti kami akan memberi cobaan kepada kamu dengan sedikit ketakutan, kelaparan, kekurangan harta, jiwa, dan buah-buahan. Dan berikanlah berita gembira kepada orang-orang yang bersabar". (QS Al-Baqarah/2:155)

31 Buya Hamka, Jihat melawan Hawa Napsu adalah jihat paling akbar: Cerama jihat rekaman Buya Hamka, (ditranskrip pada tanggal tanggal 5 Nopemver 2010 jam 11.30 wit

32 H.M. Arifin, Psikologi dan beberapa Aspek Kehidupan Rohaniah Manusia, (Cet. II; Jakarta: Bulan Bintang, 1977), h.77. 
Jihad dan sabar bukanlah dua buah sikap yang bertentangan tetapi adalah dua buah sikap yang saling menunjang dimana untuk Jihad itu diperlukan kesabaran. Dua buah ayat Makiyah lainnya bisa dijadikan sebagai argumentasi bahwa Jihad itu bukanlah semacam perang fisik yang ditujukan buat orang-orang kafir. Dalam surat Al-Hajj ayat 78 dapat kita baca sbb:

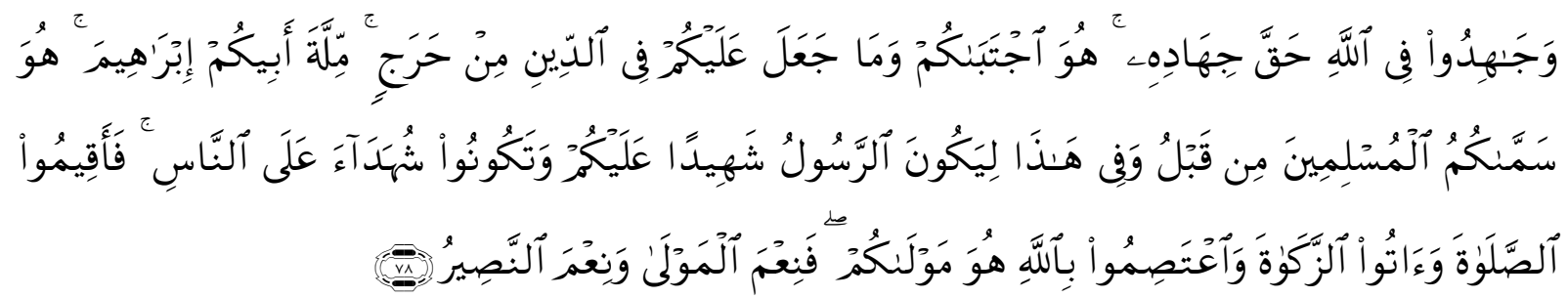

Terjemahnya:

"Dan berjihadlah kamu pada jalan Allah dengan Jihad yang sebenar-benarnya. Dia telah memilih kamu dan Dia sekali-kali tidak menjadikan untuk kamu dalam agama suatu kesempitan. (Ikutilah) agama orang tuamu Ibrahim. Dia (Allah) telah menamai kamu sekalian orang-orang Muslim dari dahulu[993], dan (begitu pula) dalam (Al Quran) ini, supaya Rasul itu menjadi saksi atas dirimu dan supaya kamu semua menjadi saksi atas segenap manusia, Maka dirikanlah sembahyang, tunaikanlah zakat dan berpeganglah kamu pada tali Allah. Dia adalah Pelindungmu, Maka Dialah Sebaik-baik pelindung dan sebaik- baik penolong”.

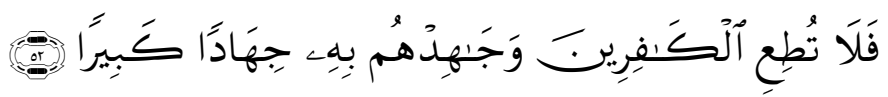

Terjemahnya:

"Maka janganlah engkau menuruti kaum kafir, dan berjuanglah (jahid) dengan ini melawan mereka dengan perjuangan (jihadan) yang hebat".

Pada ayat ini yang dituju oleh dlamir (kata ganti) "bihi" (dengan ini) ialah al-Quran sebagaimana ditunjukkan oleh hubungan ayat ini dan ayat sebelum dan sesudahnya. Dalam dua ayat tersebut (QS. 22:78 dan 25:52), terang sekali bahwa kaum Muslimin diperintahkan untuk berjihad yang pada ayat pertama dimana Jihad tersebut dilakukan demi mendekatkan diri kepada Allah, sedangkan pada ayat kedua jihad tersebut diarahkan kepada kaum kafir. Kedua-dua jihad tersebut bukanlah semacam perang fisik, dengan mempergunakan "pedang", tetapi semacam Jihad rohani "Watawa saubil haqqi" dengan mempergunakan al-Quran. Oleh karena itu perjuangan untuk mendekatkan diri kepada Allah dan untuk menundukkan hawa nafsu serta untuk mengalahkan kaum kafir bukanlah dengan menggunakan pedang melainkan dengan al-Quran.

\section{Jihad Memerangi Kebodohan dan Kemiskinan}

Berikut ini saya kutip puisi Taufil Islmail, berjihad melawan hedonistik, jihad melawan rasa malu, jihad melawan pencuri pajak, jihad melawan pencuri bank centruty, jihad melawan para koruptor yang selalu berpikir kotor, jihad melawan pemerintah yang menghardik rakyatnya.33 Dan semua orang yang telah membuat kemiskinan dan kebodohan sturktural khususnya di Indonesia wajib diperangi sesuai tingkat kemapuan masing-masing.

Jihad melawan segala macam bentuk penyelewengan yang bertentangan norma-norma budaya dan kesepakatan sosial kemasyarakatan yang dibentuk dalam UU, sebuah ketatanegaraan, peraturan

33 Taufik Ismail (57 tahun) Jihat Melawan Kebodohan dan Kemiskinan yang dipelihara oleh Negara. Siaran Lansung TV One pada tanggal 19 Agustur 2010 jam 20: 13 wit 
pemerintah harus ada militansi jihad untuk mempertahankan dari gangguan dan ancakan yang datang dari luar maupun dari dalam demi menjaga kemaslahatan umat dan penyerahan diri semata kepada Allah. Hemat penulis inilah jihad yang perlu dalam konteks kekinian.

\section{KESIMPULAN}

1. Makna jihad dalam al-Quran terjadi pemahaman yang bertingkat sesuai dengan karakter budaya dan kedalam ilmu yang dipahami dalam al-Quran.

2. Pemaparan ayat dapat dipahami bawha makna jihad dalam al-Quran pada umunya tidak ada yang mengarah pada jihad fisik seperti difahami oleh sebagian Islam jalur keras, tetapi boleh dilakukan dalam kondisi tertentu jika meneggakan kehormatan dan katahuidan.

3. Perlu paradigma baru pemahaman makna jihad yang relevan dengan kondisi dewasa ini, khususnya bangsa Indonesia untuk mmberikan pilihan-pilihan model jihad yang lebih besar pengaruhnya terhadap perbaikan kualitas hidup masyarakat Indonesia seperti berjihad melawan berbagai macam ketidakadilan, jihad melawan korupsi, dan kebodohan. Jihad harus memiliki strategi yang jitu tidak boleh hanya mengandalkan semangat dalam melakukan aktifitas kemaslahatan umat. Inilah jihad yang menurut penulis lebih besar pengaruhnya terhadap ekosistem kehidupan manusia, dibanding jihad yang sifat fisikli merusak pola hidup masayarakat dan berbahaya terhadap ekosistem kemanusiaan.

\section{DAFTAR PUSTAKA}

Abu Khalil, Syauqi. Atlas Al-Quran, Membuktikan Kebenaran Fakta Sejarah yang Disampaikan Alquran secara Akurat disertai Peta dan Foto, Dar al-Fikr Damaskus, Almahira Jakarta, 2008.

Al-Bayan, Shahih Bukhari Muslim, Jabal, Bandung, 2008.

Arifin, H.M. Psikologi Dakwah: Suatu Pengantar Cet. VI;Jakarta:Bumi Putra, 2004.

Arifin, H.M. Psikologi dan beberapa Aspek Kehidupan Rohaniah Manusia Cet. II; Jakarta: Bulan Bintang, 1977.

Azra, Azyumardi. Ahmad Qodri Abdillah Azizy, MA, A. Chaeruddin, SH., etc. Ensiklopedi Tematis Dunia Islam, Penerbit PT. Ichtiar Baru Van Hoeve, Jakarta, 2008, Editor : Taufik Abdullah, Prof. Dr. M. Quraish Shihab, Prof. Dr. H. Ahmad Sukardja, MA.

Al-Hafizh Zaki Al-Din 'Abd Al-'Azhum Al Mundziri, Ringkasan Shahih Muslim, Al-Maktab AlIslami, Beirut, dan PT. Mizan Pustaka, Bandung, 2008.

Alquran.bahagia.us, keislaman.com, dunia-islam.com, Al-Quran web, PT. Gilland Ganesha, 2008.

Departemen Agama RI, Yayasan Penyelenggara Penerjemah/Penafsir Al-Quran, Syaamil Al-Quran Terjemah Per-Kata, Syaamil International, 2007. 
Fuad Abdul, Baqie Muhammad. Nu'jamul Mufahras li Afadhil Qur'an, Beirut: Dar El Marefah. 2005.

Munawwir, A.W. Kamus Al Munawwir Arab-Indonesia, (Surabaya: Pustaka Progresif), hal 217.

Muhammad, Husein, rahimac 2000 cbn.net.id. 2003. Dikase pada tanggal 20 Oktober 2010 pada www.http.website rahima com.id.

Shihab, M. Quraish, Wawasan Al-Quran Tafsir Maudhu'i atas Pelbagai Persoalan Umat,( Bandung: Penerbit Mizan), 2007.

Nawawi, Imam, Riyādh ash-Shālihīn, Jami’ Manshur Asy Sya’ibi bi Jarrah. 2002

Muhammad Fu'ad Abdul Baqi, Mutiara Hadist Shahih Bukhari Muslim, PT. Bina Ilmu, 1979.

M. Nashiruddin Al-Albani, Ringkasan Shahih Bukhari, Maktabah al-Ma'arif, Riyadh, dan Gema Insani, Jakarta, 2008.

Muhammad Nasib Ar-Rifa'i, Kemudahan dari Allah, Ringkasan Tafsir Ibnu Katsir, Maktabah alMa’arif, Riyadh, dan Gema Insani, Jakarta, 1999.

Shihab, M. Quraish. Wawasan Al-Quran, Tafsir Maudhu'i atas Pelbagai Persoalan Umat, Penerbit Mizan, Bandung, 1997.

Sami bin Abdullah bin Ahmad al-Maghluts, Atlas Sejarah Para Nabi dan Rasul, Mendalami Nilainilai Kehidupan yang Dijalani Para Utusan Allah, Obeikan Riyadh, Almahira Jakarta, 2008.

Tim DISBINTALAD (Drs. A. Nazri Adlany, Drs. Hanafi Tamam, Drs. A. Faruq Nasution), Al-Quran Terjemah Indonesia, Penerbit PT. Sari Agung, Jakarta, 2004 